due to $E$. S. Gould, who first uncovered discrepancies, and to $J$. $K$. Hurst, who repeated much of the dubious earlier work.

[58] F. R. Nordmeyer, H. Taube, J. Am. Chem. Soc. 88 (1966) 4295; 90 (1968) 1162.

[59] The relation between reducibility of the ligands and their effectiveness in mediating electron transfer was developed in an earlier paper. E. S. Gould, H. Taube, J. Am. Chem. Soc. 86 (1964) 1318.

[60] D. K. Sebera, H. Taube, J. Am. Chem. Soc. 83 (1961) 1785.

[61] See for example: E. S. Gould, J. Am. Chem. Soc. 94 (1972) 4360.

[62] J. F. Endicott, H. Taube, J. Am. Chem. Soc. 84 (1962) 4989; 86 (1964) 1686; Inorg. Chem. 4 (1965) 437.

[63] K. Gleu, K. Breuel, Z. Anorg. Allg. Chem. 237 (1938) 335

[64] R. Gaunder, H. Taube, Inorg. Chem. 9 (1970) 2627.

[65] A. Anderson, N. A. Bonner, J. Am. Chem. Soc. 76 (1954) 3826.

[66] Indirect evidence, which is quite convincing, suggests the outer sphere self exchange rate for $\left[\mathrm{Cr}\left(\mathrm{H}_{2} \mathrm{O}\right)_{6}\right]^{3 \oplus} /\left[\mathrm{Cr}\left(\mathrm{H}_{2} \mathrm{O}\right)_{6}\right]^{2 \oplus}$ to be ca. $5 \times 10^{-10}$ $\mathrm{M}^{-1} \mathrm{~s}^{-1}$. W. S. Melvin, A. Haim, Inorg. Chem. 16 (1977) 2016.

[67] T. J. Meyer, H. Taube, Inorg. Chem. 7 (1968) 2369.

[68] H. D. Stynes, J. A. Ibers, Inorg. Chem. 10 (1971) 2304.

[69] Calculations of the barrier associated with inner sphere electron reorganization leave room for a nonadiabaticity factor of a few orders of magnitude. See J. F. Endicott, K. Krishan, T. Ramasami, F. P. Rotzinger [1], p. 141 .

[70] S. S. Isied, H. Taube, Inorg. Chem. 15 (1976) 3070.

[71] T. J. Meyer, H. Taube, Inorg. Chem. 7 (1968) 2361.

[72] D. E. Harrison, H. Taube, J. Am. Chem. Soc. 89 (1967) 5706.

[73] R. Robson, H. Taube, J. Am. Chem. Soc. 89 (1967) 6487; J. French, H. Taube, J. Am. Chem. Soc. 91 (1969) 6951; earliest example: P. Saffir, J. Am. Chem. Soc. 82 (1960) 13.

[74] M. Z. Hoffman, M. Simic, J. Am. Chem. Soc. 94 (1972) 1957.

[75] a) S. S. Isied, J. Am. Chem. Soc. 95 (1973) 8198; b) In an earlier attempt, Kirk Roberts tried the simple procedure of mixing the $\mathrm{Co}^{\mathrm{III}}$ complex with $\left[\left(\mathrm{NH}_{3}\right)_{5} \mathrm{Ru}\left(\mathrm{H}_{2} \mathrm{O}\right)\right]^{2 \oplus}$. Substitution is too slow relative to intramolecular transfer for the method to work in these systems.

[76] H. Fischer, G. M. Tom, H. Taube, J. Am. Chem. Soc. 98 (1976) 5512.

[77] L. Schäffer, unpublished.

[78] N. E. Dixon, G. A. Lawrance, P. A. Lay, A. M. Sargeson, Inorg. Chem. 22 (1983) 846.
[79] D. G. Gaswick, A. Haim, J. Am. Chem. Soc. 96 (1974) 7845.

[80] A. Haim see [1], p. 273.

[81] J. R. Winkler, D. G. Nocera, K. M. Yocom, E. Bordignon, H. B. Gray, J. Am. Chem. Soc. 104 (1982) 5798

[82] S. S. Isied, G. Worosila, S. J. Atherton, J. Am. Chem. Soc. 104 (1982) 7659.

[83] The level of current activity in the field can be gauged by the recent review of the subject of mixed valence molecules based on $\pi d^{5} / \pi d^{6}$ couples by $C$. Creutz: see [1], p. 1.

[84] G. C. Allen, N. S. Hush, Prog. Inorg. Chem. 8 (1967) 357.

[85] N. S. Hush, Prog. Inorg. Chem. 8 (1967) 391.

[86] M. B. Robin, P. Day, Adv. Inorg. Chem. Radiochem. 10 (1967) 247.

[87] C. Creutz, H. Taube, J. Am. Chem. Soc. 91 (1969) 3988; 95 (1973) 1086.

[88] D. O. Cowan, F. Kaufman, J. Am. Chem. Soc. 92 (1970) 219.

[89] P. Ford, F. P. De Rudd, R. Gaunder, H. Taube, J. Am. Chem. Soc. 90 (1968) 1187.

[90] R. S. Mulliken, W. B. Person: Molecular Complexes, Wiley, New York 1969, Chapt. 2.

[91] B. Mayoh, P. Day, J. Am. Chem. Soc. 94 (1972) 2885; Inorg. Chem. 13 (1974) 2273.

[92] G. M. Tom, C. Creutz, H. Taube, J. Am. Chem, Soc. 96 (1974) 7828 .

[93] J. E. Sutton, P. M. Sutton, H. Taube, Inorg. Chem. 18 (1979) 1017; J. E. Sutton, H. Taube, Inorg. Chem. 20 (1981) 3125.

[94] N. Sutin in G. L. Eichhorn: Inorganic Biochemistry, Vol. 2, Elsevier, New York 1973, p. 611.

[95] G. M. Brown, H. J. Krentzien, M. Abe, H. Taube, Inorg. Chem. 18 (1979) 3374.

[96] P. A. Lay, R. H. Magnuson, H. Taube, J. Am. Chem. Soc. 105 (1983) 2507.

[97] Spectroscopic studies by J. Ferguson et al. (Australia National University) are in progress.

[98] R. A. Sheldon, J. Kochi: Metal Caralyzed Oxidations of Organic Compounds, Academic Press, New York 1981.

[99] P. Ford, D. Wink, J. Dibenedetto [1], p. 213.

[100] T. J. Meyer [1], p. 389.

\title{
"... to make Chemistry more Applicable and Generally Beneficial"-The Transition in Scientific Perspective in Eighteenth Century Chemistry**
}

\author{
By Christoph Meinel*
}

In 1751, the Swedish chemist Johan Gottschalk Wallerius first differentiated between "pure" and "applied" chemistry, a distinction which was quickly adopted by the other branches of science. Behind this was a new scientific concept of chemistry which emphasized the importance of applying chemistry's accumulated knowledge and its capabilities of providing for the general economic benefit. It also provided chemistry with a new position within the hierarchy of the sciences as well as with a new function in society. The reasons behind and causes of the change in scientific perspective associated with this concept point to the social and institutional conditions under which this field has developed into an independent academic discipline.

[*] Dr. C. Meinel

Institut für Geschichte der Naturwissenschaften,

Mathematik und Technik der Universität Bundesstrasse 55, D-2000 Hamburg 13 (FRG)

[**] Based on a discussion paper "Pure and Applied Chemistry - The Foundation of a New Identity in Eighteenth-Century Chemistry" at the 29 th IUPAC-Congress, Cologne, June 6, 1983.

\section{The "Chemical Revolution"}

During the Age of Enlightenment, chemistry broke with its humble role as an auxiliary adjunct science to medicine, to attain the position of a well-respected and even fashionable science, represented on the faculties of nearly all uni- 
versities. The dynamics involved in this process have always attracted the attention of historians of science; for three aspects make this transition worthy of study.

Firstly, even though chemistry had made important practical and theoretical contributions, the "Chemical Revolution" occurred relatively late when measured against the developments in astronomy and physics from Copernicus to Newton, i.e. in relation to the "Scientific Revolution" as such. Herbert Butterfield consequently spoke of a "postponed scientific revolution in chemistry" ${ }^{[1]}$, and strangely enough, the chemists of that time were very conscious of this. In the French Encyclopédie ${ }^{[2]}$, which outranged all other contemporary works as the voice of the Enlightenment, Gabriel François Venel (17231775) recognized as early as 1753 the necessity of a "new Paracelsus" who would raise chemistry to the rank of a true science: "Il est clair que la révolution qui placeroit la Chimie dans le rang qu'elle mérite, qui la mettroit au moins à coté de la Physique calculée; que cette révolution, dis-je, ne peut être operée que par un chimiste habile, enthousiaste, et hardi, qui se trouvant dans une position favorable, et profitant habilement de quelques circonstances heureuses, sauroit réveiller l'attention des savans, d'abord par une ostentation bruyante, par un ton décidé et affirmatif, et ensuite par des raisons, si ses premières armes avoient entamé le préjugé" ${ }^{2}$.

Secondly, the emancipation of chemistry had to do with a fundamental modification of theory. The generally accepted premise up to that time had been that all combustion phenomena could be explained by phlogiston, thought to be a volatile constituent of flammable materials. This theory was replaced by Lavoisier's theory of oxidation. With the acceptance of this new theory, chemistry gained not only a comprehensive theoretical basis, but also a new terminology, making it literally impossible for supporters of the old and new schools of thought to understand one another. For this reason, Thomas $S$. Kuhn views this process as a typical example of scientific revolutions and, at the same time, as confirmation of his controversial thesis that advances in scientific development do not occur on a cumulative-evolutionary basis, but rather take revolutionary leaps and bounds, expressed in changes of paradigms $s^{[3]} . K u h n$ is in accord with the older literature on the history of chemistry, maintaining that it was just this replacement of the phlogiston theory by the oxidation theory, which was responsible for chemistry's breakthrough and subsequent scientific success. Developing Kuhn's position, Elisabeth Ströker ${ }^{[4]}$ recently examined the prerequisites for crisis and ramifications of this paradigm change on a more theoretically and historically differentiated basis; however, she is almost exclusively concerned with alterations in the cognitive area of chemical knowledge and theories, whereas Kuhn alluded to the social components in the process of scientific change.

It is this third aspect which makes the history of chemistry in the eighteenth century so fascinating. For not only did the entire social structure of the scientific community alter itself, but also the position of chemistry within the hierarchy of both the sciences and society was changed. Chemists began to see themselves as representatives of an independent academic discipline, experiencing the neces- sary acknowledgement from outside their field and forming regional or vernacular communities, enabling them to develop the common forms of scientific communication still in use today. Chemistry can lay claim to the fact that it produced the first specialized journal in a scientific field, published in 1778, and the first international scientists' gathering ever held, in 1786. Not long ago, Karl Hufbauer convincingly described this process of breaking away from the "République des Lettres", of its institutionalization, professional integration and communication, using as his example the German chemical community ${ }^{[5]}$.

But neither the alteration of the central paradigm nor the change in the social structure of the scientific community can alone adequately explain the astonishing impetus experienced by chemistry in the eighteenth century. This can least of all be accomplished by means of the traditional allusion to Lavoisier's reform, since pre-Lavoisier chemistry can only partially be identified with the phlogiston hypothesis, and in the post-Lavoisier period chemistry can only be associated to a limited extent relation to the oxidation theory. In "Elementa Chemiae" (Leyden 1732) by Herman Boerhaave, one of the most influential textbooks of its time, the term "phlogiston" does not appear. And as early as the first third of the nineteenth century the relationship between generic and specific properties of substances, an idea central to Lavoisier's reform, had already been dismissed. It is important to note, however, that of the 46 chairs in chemistry not directly related to a medical discipline that were instituted during the eighteenth century in German-speaking countries alone, around $70 \%$ had been set up before 1790 , a time when it was impossible to speak of any influence of Lavoisier's revolution in Germany.

The rise, establishment, and evolution of sciences are, of course, also social developments which can be traced back to certain groups of scientists. Thus, the intrinsic development of chemical theories, knowledge, and capabilities accompany the crystallization of specific behavior patterns and strategies, the purpose of which is to form the social and institutional basis for their own activities. For this reason the "scientific community" should be understood within the context of argumentation and action in which cognitive elements and institutionalization strategies converge, generating the self-understanding, unity, norms, and values important for just this group on an disciplinary, social and institutional level ${ }^{[6]}$. I choose to call these collective relationships a scientific orientation complex in order to overcome the unserviceable antithesis of internal and external factors of scientific development, established in 1931 by the Marxist school of science history ${ }^{[7]}$. It can be demonstrated in the history of chemistry that it was just such a comprehensive orientation complex which in the middle of the eighteenth century experienced a fundamental re-orientation, establishing the direction critical to the evolvement and further development of the discipline.

\section{The Status of the Field}

The origins of chemistry as an academic discipline lie in the seventeenth century. The Paracelsians had introduced 
the therapeutic application of chemical medicines, thereby founding the field of chemiatrics. In 1609 Johannes Hartmann (1568-1631) was vested with the first chair in this new area of study at Marburg University. The alchemical leanings of the landgrave no doubt played a part in his appointment. Two generations later this discipline was already to be found at numerous universities, functioning as an auxiliary adjunct to medicine.

Initially, of course, chemistry had no easy position. The representatives of academic science greatly mistrusted the air of alchemical obscurity surrounding it. More important, with chemistry a whole new type of science had penetrated the halls of the traditional educational institution, the University. For chemistry's real place was not at the rostrum, but in the laboratory, where, although no research and experimentation in the modern-day sense was conducted, the work was performed manually with a practical and purposeful intent. This stood in contrast to the other disciplines, including medicine, which supported the inveterate scientific ideal. The professor of chemistry, who first had to brush the soot and dirt from his lab apron before congregating with his more respectable colleagues from other faculties, was a figure who represented a striking contrast to the scholarly ideal of the baroque period, a man to whom in the most literal sense the taint of the nonacademic, the crafts, and the unclean adhered.

This situation was not to change very quickly, for the low status of chemistry within the academic hierarchy was institutionally and structurally defined. Professorships exclusively devoted to one particular subject were unknown; instead, each faculty maintained its own specific hierarchy, where advancement was largely based on seniority; here the differences in remuneration as well as the possibilities for lucrative work on the side played no small role. Within the faculties of medicine, this almost always meant that the medical professor of lowest rank lectured on chemistry as well as on pharmacy, botany, or anatomy. As soon as the opportunity arose, this professor then naturally advanced to the next highest position, finally becoming Professor primarius and could then combine his subject with a profitable private practice or with a position as physician to the prince. This system of advancement, a relic from the medieval university, maintained itself long into the eighteenth century. As long as it existed, it prohibited the development of professorships devoted exclusively to one particular science, for a doctor could hardly afford to place his professional aspirations on one of the subordinate subjects.

The reason for chemistry's bad image obviously lay in the concept of science itself, this having concerned itself primarily with a speculative and contemplative scientific ideal, seeing the search for essential truths as its main purpose. Everything else belonged to the arts. Even such a first-class authority on chemistry as Daniel Sennert (15721637) denied chemistry the status of "scientia" and reserved the right of researching into the causes of natural phenomena to natural philosophy (physica) alone, limiting chemistry to the narrow field of preparative manufacture with the emphasis on a pharmaceutical objective. This judgement was to determine the image of the subject for a considerable time. In 1786 no less than Immanuel Kant was still of the opinion that chemistry could be "nothing more than a systematic art or experimental doctrine, but never become a true science, because the principles thereof are solely empirical, envisioning no a priori representation of perception"[8].

As long as the empirical acquisition of knowledge and practical laboratory work stigmatized the subject's general esteem, the road to the autonomous development of the discipline would remain a long one.

The chemists of the Enlightenment, therefore, did everything in their power to weaken the prejudice that their discipline was simply a practical craft, a kind of "ars mechanica", without scientific character. They most certainly had recognized that their own dilemma was not so much a result of inner disciplinary deficiencies as due to the institutional conditions peculiar to their field of study. In this way a special literary tradition of doctrinal publications developed, the goal of which was to solicit support for chemistry as a distinct science in its own right and to make a broader public conscious of its true value ${ }^{[9]}$.

\section{Pure and Applied Chemistry}

Under the circumstances described here, doctrinal guidelines were formed for the further development of the discipline enabling chemistry to overcome its formalistic division into a theoretical science, on the one hand, and a practical handicraft, on the other, a distinction which was perceived as inhibiting further development; this was the distinction between "pure" and "applied" chemistry, which exists to this day ${ }^{[10]}$. Actually, this twin notion occurred for the first time in its modern-day sense in the field of chemistry. In the course of the nineteenth century it was adopted by the other sciences. This represented more than a change in terminology, however, and, more accurately, it originated in the desire to formulate a new scientific concept of chemistry in order to endow its level of knowledge and its capabilities with a new purpose. From this time on, the decisive factor in determining the relative worth of the field was not to be the type of work carried out, whether practical or theoretical, but rather the research objective itself and its relevance to society. In the case of pure chemistry, this goal was to delve into the causes and apparent laws governing natural phenomena related to matter; applied chemistry was to exploit these insights for the benefit of mankind by solving concrete everyday problems. The fact that both pure and applied chemistry were to closely ally theoretical reason with experimental practice was seen as an obvious prerequisite.

Fortunately, it is possible to pinpoint the circumstances which led to this new concept of chemistry more precisely. In 1749 , the first chair of chemistry was set up at the University of Uppsala. Up to this time, lectures in chemistry had not existed in Swedish universities, despite the fact that this country, rich in mineral resources, exhibited a pragmatically oriented mineral-chemical and metallurgical tradition. The mines at Falun and their state assay office were well-known throughout Europe. The government commission responsible for the institution of the new chair 
in chemistry had ordained the integration of the chair into the philosophical faculty, where students of the mining profession, as well as of economics and administrative science, obtained their general education. This was done, even though elsewhere in Europe chemistry was a self-evident part of the faculty of medicine. The appointment offer first went to Georg Brandt (1694-1768), director of the laboratory of the Board of Mines in Stockholm and assay master of the Royal Mint. Upon his refusal, the position was offered to Johan Gottschalk Wallerius (1709-1785), who had maintained a private chemical and metallurgical laboratory at the University of Uppsala from 1738 . He was well-known, even outside Sweden, as the author of a handbook on mineralogy. In July 1750, Wallerius accepted his new position as the first professor of chemistry in Sweden. The rector of the University had requested him to expound on the reasons for bestowing the privileges of academia on chemistry in his inaugural lecture-at this time still a controversial topic!

Even though the manuscript of his lecture no longer exists, there is reason to believe that Wallerius answered the question in the affirmative, just as Boerhaave's successor in Leyden, Hieronymus David Gaubius. In 1731 Gaubius had dedicated his "Oratio inauguralis qua ostenditur Chemiam artibus academicis jure esse inserendam" to just this topic and had also had it published. Wallerius knew this publication.

Among other duties, the new professor of chemistry was to hold lectures on chemistry, metallurgy, and pharmacy. However, he was also to examine the students of medicine in pharmacy, chemistry, and the art of writing prescriptions. The king himself had insisted that this examination be conducted by a chemist on the philosophical faculty. Understandably, the professors on the faculty of medicine felt this to be a scandalous infringement of their innate scientific and, of course, financial rights, for it meant their forgoing the not unprofitable examination fees, which reduced their not exactly lucrative salaries even further. The spokesman for their cause was none other than Carl Linnaeus (1707-1778). Originator of the modern classification system for plants and professor of botany, dietetics, and Materia Medica in Uppsala, he was also president of the Stockholm Academy of Sciences and physician to the king. Nevertheless, his objection remained unsuccessful. The professorship in chemistry stayed with the philosophical faculty, keeping its controversial examination privileges. Thus, its institutional framework was established.

In his autobiography ${ }^{[1]}$, however, Wallerius recalls that initially no-one could form a true picture of just exactly what chemistry was. To publicize his field and further his

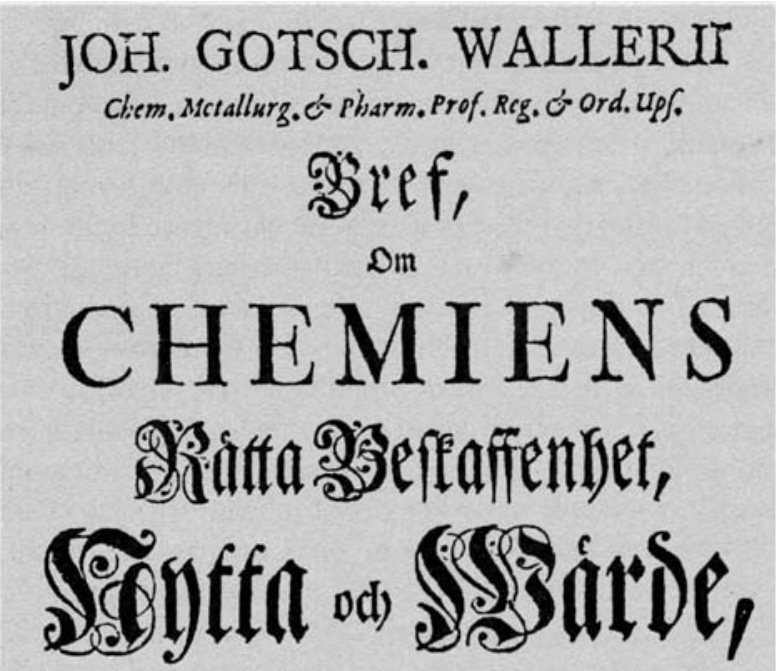

S्gil N. N. ifmerfintot,

Od) af fonom til grydet befordrast.

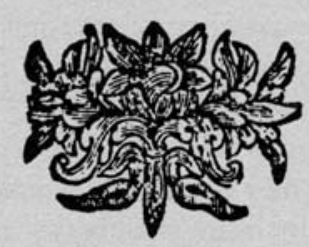

STOCXYHOLM OD) UPSALA,

SQB GOT'TFRIED KIESEWETTER. I 751



Fig. 1. In this "open letter" by Johan Gottschalk Wallerius, dated 10th August 1751, the new and promising distinction between Pure and Applied Chemistry was used for the first time. (Reproduced by permission of the Niedersächsische Staats- und Universitătsbibliothek, Göttingen.) 
own cause, he had a small essay printed in Swedish in the form of a letter addressed to an unknown person, in which he introduced the true object of the study, as well as the use and value of chemistry, going into great detail (see Fig. 1). At the very beginning, Wallerius coined the conceptual distinction between "pure" and "applied" chemistry. The latter "Chemia applicata" was emphasized by him, and considering the previous events, it is hardly surprising that Wallerius was less concerned with the medical and pharmaceutical applications of chemistry than he was with its agricultural, metallurgical, and mineralogical uses, feeling that these areas held the highest economic promise.

Whereas the Swedish "Bref" was directed at students and the general public, Wallerius addressed a Latin dissertation "De nexu Chemiae cum utilitate Reipublicae" (Stockholm 1751) of the same year to the academic world and to those politically responsible for the country. Prefacing the work were no less than four Latin, Swedish, and French dedications to eminent personages. The main theme of this work, which was publicly defended by a certain Lorenz Hiortzberg under the chairmanship of Wallerius, was the distinction between pure and applied chemistry as well as the political and economic uses of the latter. Again, mineral chemistry and metallurgy were the fields in which the fruits of this science seemed closest at hand, while the profitability of chemical medicines was treated rather distantly. In view of the doubtful therapeutical successes achieved by the potent inorganic medicines then administered, this is certainly understandable.

The decisive factor which led to the acceptance and propagation of "pure and applied" chemistry was the general chemistry textbook by Wallerius ("Chemia Physica", Stockholm 1759), which he first published in Swedish and then personally translated into Latin, the language of academic Europe (Stockholm, 1760). Shortly thereafter, translations into German also appeared. This work played an important role in the history of chemistry textbooks in that it gave birth to a whole new generation of textbooks, written in the vernacular, the express purpose of which was to represent chemistry as an integral part of the physical natural sciences without reducing it to the level of medical or pharmaceutical interests. Its title "Chemia Physica" was intended to express just this general scientific concern. In this textbook Wallerius took the opportunity to develop his scientific concept of chemistry even further, for now he had realized that by consistently classifying the field in accordance with its objective and effect two things would occur: not only would the old separation of theory and practice lose weight, but so would the tiresome dispute over the definition of chemistry as a science or as an art. Instead, he regarded all subdivisions of applied chemistry as independent self-contained sciences which comprised both theoretical and practical aspects.

In choosing the twin concept "pure and applied" chemistry, mathematics had been openly declared as the model, although the mathematical terms had an entirely different meaning. "Pure" mathematics meant that part of the mathematical sciences which dealt with numbers only as intellectually perceptible, incorporeal patterns, whereas "applied" mathematics, according to the literal translation of "mathematica mixta", meant that part of mathematics which dealt with the numerical relationships of real things, perceptible to the senses. The aspect of utility and general benefit which has been connected with the concept of applied science since Wallerius was nowhere to be found in "applied mathematics" until the end of the nineteenth century. It is therefore worthy of attention, and most certainly no chance occurrence, that the modern definition of this twin concept originated in chemistry, thereafter spreading to all other sciences and European languages during the nineteenth century. The historical development of its influence will not be expanded upon here ${ }^{[12]}$. It should be mentioned, however, that the key role in its propagation was played by the Greifswald chemistry professor Christian Ehrenfried Weigel (1748-1831). Until 1815 the university at which he lectured was part of the Swedish Kingdom, so that as a result he was exceedingly familiar with the Scandinavian chemical tradition ${ }^{[131}$. In addition to translating French and Swedish authors, he was also publicly active as a proponent of an autonomous chemical science by means of his own textbooks and popular writings. He was well-known among his contemporaries as the inventor of the water-jacketed condenser, which today is falsely known as Liebig's condenser.

\section{A Concept of Science in the Enlightenment}

Wallerius' scientific concept of chemistry would not have been such a sudden and lasting success had it solely originated from a single Swedish chemist. In principle, the idea had been around for some time and it was Wallerius who merely succeeded in pinpointing and naming this new orientation of chemistry, which had reached a turning point around the middle of the eighteenth century. For almost simultaneously, it was possible to find Mikhail Lomonosov (1711-1765) making very related deliberations in Petersburg, in addition to the circle of authors of the French Encyclopedie. All of these are related by their common attempt to overcome the earlier contemplative ideal of science with its overrating of the theoretical, in order to replace it with a new bourgeois concept of science, which in turn contained the idea of progress and of actively molding the world. This new evaluation of chemistry and the higher status of its range of application was thus an inherent part of the purpose of the Enlightenment in putting rationality and the individual pursuit of happiness into social practice. The reason that this process began earlier and more noticeably in chemistry than in the other natural sciences lies in the fact that applied chemistry had already achieved undisputed successes; and due to its level of development, further useful discoveries could be expected.

Chemistry's understanding of its own role and its status was influenced more and more by utilitarian thought in the eighteenth century. Hardly an author wrote a new work without expressly informing the public of its far-reaching and direct benefits. Even textbooks were laid out according to the widely circulated "Elementa Chemiae" by Boerhaave, so that each "processus" was divided into "apparatus" (preparation) and "usus" (application). Seldom have rhetorical elements penetrated so deeply into the inner 
structure of a discipline as in this case. Even in defining its objective and essence, the aspect of general benefit, as a rule, played a very important role in determining just what chemistry was. It would be premature to dismiss this only as rhetoric. Of course, it was also a question of safeguarding social and institutional support for their discipline, as well as obtaining new professorships, finances for a laboratory, or funds for an expensive experimental lecture. At the same time, it expressed chemistry's new understanding of its own function. The most respected representatives of the discipline made utilitarianism their own deep concern and stepped forth with treatises on the properties and preparation of foods and industrial goods, on questions of heating and lighting, dyeing and stain removal. It must be remembered that the first scientific publication of Antoine Lavoisier, then 21 years of age, was an answer to a question in a contest sponsored in 1764 by the Académie des Sciences as to the best and most economical method of lighting the streets of Paris at night. Working on a wide scale for the benefit of all was considered the final and utmost purpose of scientific work. Ferdinand Wurzer (17651844 ), one of the most productive German chemists of his generation, linked his professorship of chemistry and pharmacy at the University of Marburg with a teaching position at its Staatswirtschaftliches Institut, a school of economics. Consequently, he began the introduction to his "Handbuch der populären Chemie" (Marburg an der Lahn 1806) as follows: "People are finally beginning to generally realize how necessary chemistry is in order to handle crafts, factories and matters of economy more effectively, how industry with all its beneficial consequences has risen to an especially excellent level in those countries where knowledge of chemistry and its accomplishments are valued and utilized". And he concluded with this acknowledgement: "It is my deepest wish, with this work, to pay homage to that noble spirit of our time through whose power scientific knowledge is becoming less and less the monopoly of the learned, in that the majority of the latter are everywhere visibly attempting to work for the general benefit, to speak within the grasp of the masses, and to come down to their level"'13a].

Of course, the content of such popular treatises promising to be of directly beneficial use did not always fulfill what the flowery titles and prefaces foretold. Just the same, they must have had a considerable effect. By means of their thematic variety and high circulation, they reached an extraordinarily wide public from gentlemen farmers and manufacturers to ministerial officials. Thus the contribution this kind of scientific literature made to popularizing chemistry and to the public's acceptance of its rational and utilitarian image cannot be overvalued, even if the historiography of chemistry is all too partial to the development of theories and cognitive progress, disapproving of this kind of commercial literature.

\section{Chemistry and the Economy}

In the German tradition, chemistry's preoccupation with domestic and political economy as well as its leading role in stressing its economic benefit is especially marked. The reason for this is to be found in the discipline's very close ties to cameralism, the German variant of mercantilism, related to the administrative needs of small territories. The goal of the cameralists was the welfare of the state and the "best for all", to whose end mercantile thought and the national quest for power should strive. Their programme of economic reform envisioned increasing the working population as well as the government's intake of revenue by limiting imports and deliberately encouraging trade. By means of accessibility to and better exploitation of domestic raw materials and mineral resources, it was believed feasible to economically strengthen the country, if possible to the point of self-sufficiency. The initial cameralistic encouragement of industry, primarily due to government initiatives in the production of textiles, glass, and ceramics, achieved evident successes. As a result, new problems arose in the production and raw materials sectors, presenting a challenge to chemistry's professional competence.

Johann Joachim Becher (1635-1682), a very versatile man, known to chemists as the father of the phlogiston theory, was also one of the founders of cameralism and at a time when his chemical and alchemical works were almost forgotten, his contributions to cameralistics were still the accepted standard. In 1676 Becher founded his "Kunstund Werkhaus" in Vienna, with the support of emperor Leopold I, who was greatly interested in alchemy. It was a technical teaching and research institute meant to enliven Austrian manufacturing methods. Obviously, a chemical laboratory, glassworks, and a metallurgical laboratory were included in its endowment, for encouragement of trade and technological development were accepted as the central mandate of modern government. Around the year 1700, Georg Ernst Stahl (1660-1734), the great theorist and respected teacher of a whole generation of German chemists, had expanded on Becher's hypothesis of "fatty earth" to form the phlogiston theory and was thus able to account for a great number of chemical reactions. He had also adopted Becher's doctrine of economically oriented chemical practice. The spiritual environment of Halle's Pietism, to which Stahl felt closely allied, had initiated a lively economic boom in that Prussian town even before the turn of the eighteenth century, a boom which resulted in the most modern forms of production and which influenced the building of factories, the establishment of $A$. H. Francke's Foundations, and the transformation of the Saale into a navigable river. Last but not least, the University of Halle was also founded in this period (1694), to develop a short time later into the leading Prussian university of its time. That same year, Stahl, who came from Jena, was made Professor secundarius on the faculty of medicine in the ambitious, newly founded university. He distinguished himself there with treatises on chemical metallurgy, assaying, dyeing techniques and the extraction of saltpeter. His chemical-technical masterpiece "Zymotechnia Fundamentalis" (Halle 1697) laid the foundation for the chemical interpretation of such processes as the brewing of beer, alcoholic fermentation, and the preparation of vinegar. In the year of Stahl's death, 1734, it was recommended by the translator of the German edition as a manual, with the aid of which a clever statesman could save millions in imports 
by improving domestic production. It is noticeable that pharmaceutical and medical questions play a relatively minor role in Stahl's chemical publications. His own medical system was based on an animist vitalism and therefore diametrically opposed to the iatrochemical school. Stahl believed that chemistry had little to contribute to a better understanding of the physiological and pathological processes occurring within the human organism. This conviction encouraged him to open up new areas of application for chemistry independent of medicine.

Later, it was none other than the Stahlians who carried on this impulse, freeing chemistry from its subordinate role as an auxiliary adjunct to medicine and attempting to integrate it into the economic-cameralistic doctrine of the modern state. The treasury's vital areas of interest made the relationship between economy, production, and science a most important objective of enlightened absolutist thought: mines and foundries, saltworks and porcelain manufactures, mint and glassworks, and finally the production of saltpeter for military purposes presented tasks enough for chemistry. Even the early cameralistics (Kameralwissenschaft) which originated from the domestic and rural economy, eventually recognized how much it could profit from chemically founded knowledge of substances and processes. Johann Gottlieb Eckhardt's "Vollständige Experimental-Ökonomie" (Jena 1754) was one of the first works from the tradition of husbandry to apply scientific principles to farming, thus beginning a new epoch in agricultural science which was then to result in a still rather primitive type of agricultural chemistry, as set down in Johan Gottschalk Wallerius' "Åkerbrukets chemiska Grunder" (Stockholm 1761; also published in Latin, German, French, and English editions). The theoreticians and reformers of cameralistics in the eighteenth century consciously viewed knowledge of chemical science as a basic prerequisite of their discipline, demanding the establishment of independent teaching positions in chemistry in order to instruct government administration and department of finance employees. In Göttingen, then center of cameralistics in Germany, Johann Heinrich Gottlob von Justi (1717-1771), its most important systematist, held lectures on economy, polity and administration, but also on chemistry and mineralogy. In his "Staatswirthschaft", published in 1755 , the classic textbook in this field, he demanded that an independent economics faculty be established, in which chemistry, natural history, mechanics, and politics should be instructed on a very practical level with emphasis placed on their social benefits.

It can again be assumed that Sweden was the model in this case, for there, the connection between chemistry and cameralistics had the oldest tradition ${ }^{[14]}$. As early as 1638 , a state Assay Office had been set up in the Stockholm Mines Office, which controlled the education of mining officials as well as the Swedish mines and foundries and the analyses for the Royal Mint. Then in 1750, Wallerius was appointed to the first chair in chemistry on the philosophical faculty of the University of Uppsala to give special consideration of the economic interests of the country. Subsequently, the universities of Lund and Åbo linked their new chairs in chemistry to cameralistics and not to medicine.
But later, even in Germany, professorships in chemistry existed on the newly-created Kameralfakultäten at Lautern/Heidelberg, Giessen, and Mainz.

\section{The Emerging Academic Discipline}

Thus, chemistry had conquered university territory, where it neither had to assert itself against the overpowering tradition of the medical faculties nor to defend itself against the charge of being only a handicraft. Instead, it could test its knowledge and capacities as a science in accordance with the interests of the respective governments. "To make the gifts of nature easier to use for human benefit", was the way Johann Georg Menn (1730-1781) put chemistry's real objective. "Is the real purpose of chemistry not clearly aligned with the most important intention of the State as a whole to work for the common good? Is it not also in agreement with the judgement of those who want nothing more than to see that those sciences prosper which are advantageous to each and every part of the state up to and including the tradesmen?" ${ }^{[15]}$ The shift in orientation within the discipline with regard to its contents can also be followed by studying the change in interests of chemical publications in relation to questions of commercial application.

The persuasive power and success of the new doctrine can be explained by the fact that the capacities of eighteenth century chemistry with regard to knowledge of substances, theoretical interpretation, quality of apparatus and the technical ability to realize its objectives was a great deal better adapted to the new challenges posed by the fields of metallurgy, glass and ceramics manufacture, textile processing and dyeing; better, that is, than the much more complex questions in the medical and pharmaceutical traditions, as they had been posed by Boerhaave's corpuscularian physiology and by the analysis and pharmacology of herbal substances, or by the chemo-cosmological doctrine of Paracelsism. Chemical theory was able to and was also permitted to prove itself, as this practical aspect now met with social approval and enjoyed official support. Chemistry's scientific and economic successes opened perspectives for its development into a profession and for its institutionalization as an academic discipline.

Of course, the ties to the medical faculties still existed, since future medical doctors made up by far the largest part of the students present at chemistry lectures. Only later was there a sudden increase in the number of students of pharmacy, primarily resulting from the introduction of new legal measures, which gave this area increasing importance as a breeding ground for the development of chemistry. Primarily institutional reasons therefore determined that the earliest efforts of the discipline, as "chemia physica" and as a part of general natural science, to break away from the medical faculty and become part of the philosophical faculty seldom met with lasting success. For, along with this transference, the right to examine medical candidates was almost always forfeited, resulting in the loss of a large number of the potential and paying students at lectures. For example, Johann Friedrich Gmelin (17481804) accepted a full professorship in chemistry on the 
philosophical faculty in Göttingen in 1775 , which was associated with extraordinary membership of the medical faculty. Three years later, however, he was forced to give up this position to accept a professorship on the medical faculty, despite the fact that his main scientific interests still lay in applied and industrial chemistry. Friedrich Albert Carl Gren (1760-1798) suffered a similar fate. He began as an assistant to the professor of mathematics and physics in Halle and was then employed from 1785 onwards as a teacher of political science and economics on the philosophical faculty of the university. In 1788 he accepted a full professorship in science and chemistry which, however, reverted to the medical faculty after a period of just a few months. Jena, with a student body of about 800 , was then the third largest German university after Halle and Göttingen, and was simultaneously the first German university to make a lasting institutional differentiation between chemistry and medicine. Due credit for this farsighted appointment policy must be given to the minister responsible at the time, Goethe. In 1789 he established a professorship in chemistry, pharmacy and technology there, not without strong objections from the medical staff. He appointed Johann Friedrich August Göttling (17551809 ) to this position, an apothecary whom he had sent to study in Göttingen and England at government expense $^{[16]}$.

In surveying the development of chemistry in the eighteenth century, it can be noted that neither a mere improvement in external conditions nor a revolution in Kuhn's sense had enkindled the far-reaching process of transformation enabling the field to liberate itself. In chemistry, the developing scientific community centered its attention not so much on a new and binding doctrine or theory as on a scientific orientation complex composed of rational argumentation and social action, which gave the discipline's level of knowledge and capacities a new direction; this provided chemistry with a more up-to-date form of institutionalization strategy and made a re-evaluation of its cognitive content possible. This shift in orientation equally influenced its objects of study and methods used, its formulation of objectives and self-understanding, its social role, and its institutional integration. At its turning point stood the concept of a "chemia pura et applicata", which set the stage for the autonomous development of the discipline about to take place.

\section{Departure from the Chemistry of the Enlightenment}

The historical development of chemistry as an academic subject, however, goes beyond its thus attained goal. The climax of the mutual approach of chemistry and cameralistics was reached by the first third of the nineteenth century. The doctrine, which had concentrated on general and economic benefit, had exhausted itself, especially since the hopes of obtaining immediate material advantage in this way were not fulfilled. Finally, the popularization of the subject by the movement started by the Enlightenment occasionally caused the original objectives to seem superficial and trivial. But also with regard to its content, eighteenth century chemistry had come to the limits of its theor- etical and methodological capacities when attempting to answer the ever-increasing questions from physiological and organic chemistry which the research programme dealing with quantitative combustion analysis, having received some support from Lavoisier's elemental concept, was now at a loss to deal with.

The institutional hurdles had, however, been overtaken. Chemistry had established a firm foothold in the universities. It no longer required any support from outside. In addition, chemists, especially in Germany, influenced by Romantic Naturphilosophie as well as by the neohumanistic university reforms, which originated in Berlin in 1810 , were increasingly attempting to sever themselves from their utilitarian heritage. The new guiding light was called "pure science", that is, insights gained for the purpose of knowledge and liberal education alone. Applied and technical chemistry had been elevated to the level of a university discipline, only, with a few exceptions, to again depart from the academic arena and regroup in polytechnics. No less a person than Justus Liebig (1803-1873), who came from a strong mercantile tradition of chemistry, propagated this new, solely research-oriented concept of education with amazing success and thus initiated a new shift of orientation within his discipline. His fierce attacks on proponents of the old line, including his own teacher Karl Wilhelm Gottlob Kastner (1738-1857), often overshot their mark and constituted a part of his campaign against the directly utilizable. The same is true of his polemic remarks on the plight of chemistry in Austria and Prussia, the two countries with the strongest mercantilist traditions: "Most of our statesman only know chemistry and physics as a result of the benefits they have reaped for industry and factories in foreign countries. It is, of course, natural to exploit these benefits; just as chemistry in earlier times was vassal to the doctor, so today it is used as a $\operatorname{cog}$ in the wheels of industry. ... It has never been regarded by the state as a means of intellectual education, as a natural science in the true sense of the word. A large number of the well-educated see chemistry consisting of certain simple rules, as an experimental art, useful for making soda and soap, in fabricating better iron and steel, in depositing solid colors on silk and cotton, but as research into nature it is unknown. How strange, then, that the expression education, as understood by the truly enlightened, only extends to include knowledge of classical languages, history, and literature! The question of the causes of natural phenomena and the changes occurring in everything that surrounds us in daily life is so well-adapted to the human spirit that the sciences which are supposed to supply satisfactory answers to these questions influence the cultural level of the mind more than all others"[17].

The challenge which originated in the Humboldt reform, with its overevaluation of the "humaniora" and in its new scientific ideal, was a part of chemistry from then on, and was answered in such a way that it held the seed of educational and scientific policy discussions up to the present day.

But let us recapitulate. When Herman Boerhaave (16681738) accepted the chair of chemistry at the University of Leyden in 1718 , he complained anxiously that chemistry 
was regarded as "uncouth, repulsive and tiring, excluded from the community of the learned, unknown or mistrusted by scholars; it was supposed to stink of fire, smoke, ash and rubbish, having hardly anything appealing to offer" ${ }^{\text {[18] }}$. Three generations later Johann Friedrich Gmelin (1748-1804), professor of chemistry at Göttingen, a supporter of the phlogiston theory and one of the first historians of his field, could already maintain, full of pride, that chemistry was "the idol before which all peoples, all classes, princes and subjects, clergy and secular, learned and unlearned, of high and low rank, kneel down; the favorite science of the great, the practice of which promised mountains of gold, quick reinstatement of ruined finances and of ruined health, ... the retreat of the wise searching for light and enlightenment; the most important aid to the researcher of nature, imparting knowledge to him where other sciences fail; the key to many of the secrets of nature; the chosen guiding light in the labyrinth of countless industries which nurture, bless and enrich people and states; the rational basis for the existence of foundries, of many factories, arts and handicrafts ..."[19].

Hardly eighty years had passed between these two assertions. During these years that far-reaching process of new orientation took place in chemistry, which first created the conditions necessary for its subsequent development as an autonomous academic discipline and for that change of paradigms, which we call the Chemical Revolution.

Received: March 5, 1984 [A 491 IE] German version: Angew. Chem. 96 (1984) 326 Translated by Duane Eilertson, Hamburg

[1] H. Butterfield: The Origins of Modern Science, 1300-1800, Bell, London 1957.

[2] Encyclopédie ou Dictionnaire raisonné des Sciences, des Arts et des Métiers, Tome 3, Briasson etc., Paris 1753, pp. 409-410. English translation of the quotation: "It is clear that the revolution that would place chemistry in the rank it merits would put it at least at the side of mathematical physics; this revolution, I say, can be carried out only by an able, enthusiastic, and bold chemist who, finding himself in a favorable position, and profiting ably from several fortunate circumstances, would know how to rouse the attention of learned men, first by a noisy ostentation, by a decided and affirmative manner, and then by reasons, if his first weapons would have subjugated prejudice."

[3] T. S. Kuhn: The Structure of Scientific Revolutions (International Encyclopedia of Unified Science), University of Chicago Press, Chicago, IL 1962.

[4] E. Ströker, Theoriewandel in der Wissenschaftsgeschichte-Chemie im 18. Jahrhundert, Klostermann, Frankfurt am Main 1982

[5] K. Hufbauer: The Formation of the German Chemical Community (17201795), University of California Press, Berkeley, CF 1982.

[6] P. Weingart "On a Sociological Theory of Scientific Change" in R. Whitley: Social Processes of Scientific Development, Routledge \& Kegan Paul, London 1974, p. 45-68.

[7] Science at the Cross Roads, Papers presented to the International Congress of the History of Science and Technology, London 1931, by the delegates of the U.S.S.R., Frank Cass, London 1931.

[8] I. Kant „Metaphysische Anfangsgründe der Naturwissenschaft [1786]" in W. Weischedel: Immanuel Kant Werke, vol. 8, Wissenschaftliche Buchgesellschaft, Darmstadt 1975, p. 15: ,so kann Chymie nichts mehr als systematische Kunst, oder Experimentallehre, niemals aber eigentliche Wissenschaft werden, weil die Prinzipien derselben bloß empirisch sind und keine Darstellung a priori in der Anschauung erlauben."
[9] C. Meinel "De praestantia et utilitate Chemiae. Selbstdarstellung einer jungen Disziplin im Spiegel ihres programmatischen Schriftums", Sudhoffs Arch. 65 (1981) 366

[10] C. Meinel "Theory or Practice? The Eighteenth-Century Debate on the Scientific Status of Chemistry", Ambix 30 (1983) 121.

[11] N. Zenzén "Johan Gottschalk Wallerius' Självbiografi”, Lychnos Lärdomshist. Samf. Ársb. 1953, 235.

[12] See also C. Meinel "Reine und angewandte Chemie. Die Entstehung einer neuen Wissenschaftskonzeption in der Chemie der Aufklărung", Ber. Wissenschaftsgesch. 7 (1984), in press.

[13] C. Friedrich, H. Langer, H.-J. Seidlein "Christian Ehrenfried WeigelSeine Bedeutung für die Entwicklung der pharmazeutischen Wissen schaft", Pharmazie 37 (1982) 290, 446, 514.

[13a] Wurzer's original text: „Man fängt endlich an, es allgemein einzusehen, wie nothwendig die Scheidekunst sey, um Künste, Fabriken und Gegenstände der Oekonomie besser zu behandeln; wie Betriebsamkeit mit allen ihren wohlthätigen Folgen vorzüglich in jenen Ländern in einem ausgezeichneten Grade emporkommt, in welchen chemische Kenntnisse nach Verdiensten geschätzt und benutzt werden.... Mein in nigster Wunsch ist es, durch diese Schrift jenem edlen Geiste unserer Zeit zu huldigen, kraft dessen wissenschaftliche Kenntnisse mit jedem Tag weniger das Monopol der Gelehrten bleiben, indem die entschiedenste Majorität derselben sich sichtbarlich überall bestrebt, gemeinnützig zu seyn, für den großen Haufen verständlich zu reden, und sich zu seinem Gesichtskreis herabzulassen."

[14] H. Olsson: Kemiens historia i Sverige intill år 1800 (Lychnos Bibliotek 17, 4), Almqvist \& Wiksell, Uppsala 1971.

[15] J. G. Menn: Rede von der Nothwendigkeit der Chemie, Universitätsdrukkerei, Köln 1777: „Ist ihr Zweck nicht ganz übereinstimmend mit der wichtigsten Absicht des gesammten Staates auf sein allgemeines Wohl, und auch mit dem Urtheil derjenigen, die nichts sehnlicher wünschen, als daß überall diejenigen Wissenschaften vorzüglich blühen, welche allen Gliedern des Staates und jedem besonders, bis auf den Handwerker einschlieslich, vortheithaft sind?'”

[16] H. Döbling: Die Chemie in Jena zur Goethezeit (Zeitschrift des Vereins für Thüringische Geschichte und Altertumskunde, Neue Folge, Beiheft 13), G. Fischer, Jena 1928.

[17] J. Liebig "Über das Studium der Naturwissenschaften und über den Zustand der Chemie in Preußen [1840]" in J. von Liebig: Reden und $A b$ handlungen, Winter, Leipzig 1874, p. 12: „Die meisten unserer Staatsmänner kennen die Chemie und Physik nur aus dem sichtbaren Vortheil, den beide auf Gewerbe und Fabriken in fremden Ländern ausgeübt haben; es lag natürlich nahe, der nämlichen Vortheile sich zu bemächtigen; so wie die Chemie früher dem Arzte unterthan war, so benutzte man sie jetzt als Hebel der Industrie... Als Mittel zur Geistesbildung, als Naturforschung im eigentlichsten Sinne des Wortes, ist sie von dem Staate nie in Betrachtung gezogen worden. Eine Masse von ganz unterrichteten Leuten betrachten die Chemie als eine in Regeln gebrachte Experimentirkunst, nützlich, um Soda und Seife zu machen, ein besseres Eisen und Stahl zu fabriciren, um gute solide Farben auf Seide und Baumwolle zu liefern, als Naturforschung kennen sie sie nicht. Wie sonderbar, daß der Ausdruck Bildung bei einem wahrhaft erleuchteten Volke sich nur auf die Kenntniss der classischen Sprachen, Geschichte und Literatur erstreckt! Die Frage nach den Ursachen der Naturerscheinungen, den Veränderungen von allem, was uns täglich umgiebt, ist dem regen menschlichen Geiste so angemessen, daß die Wissenschaften, welche befriedigende Antworten auf diese Fragen geben, mehr als alle anderen, Einfluss auf die Cultur des Geistes üben."

[18] H. Boerhaave: Sermo academicus de Chemia suos errores expurgante, P. v. d. Aa, Leyden, 1718 , p. 2.

[19] J. F. Gmelin: Geschichte der Chemie seit dem Wiederaufleben der Wissenschaften bis an das Ende des 18. Jahrhunderts, vol. 1, Rosenbusch, Göttingen 1797, p. 2: "der Abgott, vor welchem alle Völker und alle Stände, Fürsten und Unterthanen, geistliche und weltliche, Gelehrte und Ungelehrte, Hohe und Niedere die Kniee beugen; die Lieblingswissenschaft der Grosen, von deren glücklichen Ausübung sie sich goldene Berge, schleunige Wiederherstellung zerrütteter Finanzen, so wie zerrütteter Gesundheit, versprachen, ... die Zuflucht des Weisen, der Licht und Belehrung sucht; die wichtigste Hülfswissenschaft des Naturforschers, die ihm Aufschlus gibt, wo ihn andere Kenntnisse verlassen; der Schlüssel zu manchen Geheimnissen der Natur; der auserwählte Leitstern im Labyrinth zahlloser Gewerbe, die Menschen und Staaten ernähren, beglüken, bereichern, die vernünftige Grundlage des Hüttenwesens, vieler Fabriken, Künste und Handwerke ..." 